6-3-2016

\title{
Book Review: Denial of Violence: Ottoman Past, Turkish Present and Collective Violence against the Armenians, 1789-2009
}

Andrekos Varnava

Flinders University

Follow this and additional works at: https://digitalcommons.usf.edu/gsp

\section{Recommended Citation}

Varnava, Andrekos (2016) "Book Review: Denial of Violence: Ottoman Past, Turkish Present and Collective Violence against the Armenians, 1789-2009," Genocide Studies and Prevention: An International Journal: Vol. 10: Iss. 1: 121-123.

DOI:

http://dx.doi.org/10.5038/1911-9933.10.1.1403

Available at: https://digitalcommons.usf.edu/gsp/vol10/iss1/13

This Book Review is brought to you for free and open access by the Open Access Journals at Digital Commons @ University of South Florida. It has been accepted for inclusion in Genocide Studies and Prevention: An International Journal by an authorized editor of Digital Commons @ University of South Florida. For more information, please contact digitalcommons@usf.edu. 


\section{Book Review: Denial of Violence: Ottoman Past, Turkish Present and Collective Violence against the Armenians, 1789-2009}

Andrekos Varnava

Flinders University

Adelaide, Australia

Denial of Violence: Ottoman Past, Turkish Present and Collective Violence against the Armenians, 1789-2009

Fatma Müge Göçek

Oxford, Oxford University Press, 2014

pp. 680; Price: $£ 35.99$

Reviewed by Andrekos Varnava

Flinders University

Monumental-I use this word positively to describe the 656 page (478 pages of text) tome produced by Fatma Müge Göçek. Her account is part of a wider shift in the field of Armenian Genocide studies: from using archives to prove that the term genocide is appropriate in this context, towards more theoretically informed approaches that deal with the experiences, responses, and the aftermath. It is important to note from the outset that Göçek's Denial of Violence takes an innovative sociological-historical approach, as opposed to an archive-driven, political science, or even a sociological-political approach. Furthermore, although she is not the first Turkish scholar to openly write about the Armenian Genocide (Taner Akçam, Ayhan Aktar, Uğur Ümit Üngör and others), ${ }^{1}$ unlike the others, she infuses throughout the book a personal dimension, which is essentially her own encounter with the mass violence that looms large in the Turkish past. Göçek goes beyond exploring the fate of the Armenians and the issue of Turkish denial by addressing a more general question of why collective violence seems endemic and normal to the Turkish state and its society across generations. She argues that the act of violence against the Armenians during the Great War was an act of 'foundational violence' and therefore it has been justified by the Turkish state and accepted as normal by the Turkish people.

Standing at sixty-six pages, Göçek's introduction is an attempt to leave no stone unturned in setting up the narrative that is to follow. She does a marvellous job of situating her study alongside the broader literature and relevant theories. However, readers could be put off by the length and density of the chapters. Paradoxically, there is also a lack of historical context from both a Turkish and Armenian historical perspective as well as broader Great Power engagement. This is addressed in the chapters, but would be preferable at the start so that repetition is avoided later because it detracts from the main argument. For example, Göçek claims that the Armenian Genocide reduced the non-Muslim population from 20 percent to 4 percent at the start of the Great War. However, does she take into account the period of mass violence and ethnic cleansing after the war or not? When we finally get some context, it mostly comes in each chapter, making them very long. I would have suggested splitting the introduction and separating the historical context into a stand-alone chapter. Most importantly, there is no discussion in the introduction of her main sources; that is, the 307 authors of 356 memoirs (mostly Turkish, with some Kurdish, Armenian, and Greek). Who were these people? What role did they play in the events they describe? What role, if any, did the distance between the events and the penning of their memoirs play in influencing their writing?

The main chapters (there are four) center around the denial discourses or 'legitimisation' narratives that Göçek identified in the memoirs she consults. The first chapter aims to cover the

${ }^{1}$ Taner Akcam, From Empire to Republic: Turkish Nationalism and the Armenian Genocide, (London: Zed Books, 2004); Taner Akcam, A Shameful Act: Armenian Genocide and the Question of Turkish Responsibility, (New York: Metropolitan Books, 2006); Ayhan Aktar, "Debating the Armenian Massacres in the Last Ottoman Parliament, November - December 1918," History Workshop Journal, 64, Autumn (2007), 240-70; Ugur Ümit Üngör and Mehlet Polatel, Confiscation and Destruction: The Young Turk Seizure of Armenian Property, (London: Continuum, 2011); Taner Akcam, 'Young Turks' Crime Against Humanity: The Armenian Genocide and Ethnic Cleansing in the Ottoman Empire, (Princeton, NJ: Princeton University Press, 2012). 
period 1789 to 1907 . However, it revolves specifically around the 1894-6 Hamidian massacres and the 1896 Ottoman bank seizure. Chapter two moves onto the denial narratives concerning the Young Turks for the period 1908-1918 with the years of the Armenian Genocide, 1915 and 1916, being the crucial years of focus. The third chapter focuses on the early Republican denial discourses, that is, for the years 1919-1973. The last chapter explores how Turkish denial has continued since the 1970s, with a particular focus on justifying denial alongside the Armenian terrorism of the 1970s and 1980s. It also sees its most recent manifestation with the assassination of the journalist Hrant Dink in 2007. This structure follows closely the sources Göçek consulted, which is normally a good approach, and there was indeed a strong knowledge of the historical context. However, there is the occasional failure to reference other historical works that make similar arguments. Göçek argues that the Balkan Wars between 1912 and 1913, with the influx of displaced Muslims from the Balkans into Constantinople and Anatolia, were important in creating hostility towards Christian communities. This argument was made by Nicholas Doumanis in his excellent book (also with Oxford University Press) published only three years ago, which Göçek did not consult. ${ }^{2}$ Additionally, I was concerned by the use of the term genocide, especially in reference to Greek and Assyrian genocides. Göçek did not provide a definition of genocide, but to my mind we need to distinguish between an attempt to exterminate a people (racial, ethnic, national), which is genocide, and an attempt to expel them, which I contend is ethnic cleansing, and which may or may not involve massacres aimed at creating a climate conducive to forcing more or all of the rest of the people targeted to flee. I cannot speak with any confidence about the Assyrian case, but in the Greek case there was never any attempt by the Ottoman and Turkish authorities to exterminate the Greek or Turkish speaking Orthodox Christians. The plan was expulsion and therefore to ethnic cleanse areas in order to Turkify them, and massacres were a part of the process, but never with the aim of extermination of the entire community. In the Assyrian case, they seem to have been caught up in the attempt by over-zealous local authorities implementing the Armenian Genocide. Finally, it needs to be corrected that the mass violence in Istanbul in 1955 against the Christian population was the result of events in Cyprus and not, as Göçek claims, in response to a massacre of Turkish Cypriots by Greek Cypriots. The Turkish government and deep state were trying to jostle for position in any upcoming negotiations.

What Göçek does really well is the way she uses the words of the perpetrators of collective violence to indict themselves. She does so not by merely 'letting the sources speak', but by giving these words meaning through her skilful and theoretically inspired analysis. Göçek shows that Turkish denial of mass and collective violence against Armenians takes on historical dimensions as authors writing after the events, in some cases decades after, legitimise the mass and collective violence through their nationalist and one-sided interpretation of historically contested events. This is how the denial of violence is continued. In this way, Göçek delves into socio-psychological explanations and the socio-psychological effects in the Turkish-Armenian relationship. Above all her strong points, she shows that emotion rather than reason, empathy, and compassion have been allowed to dominate Turkish responses.

I have described the book as monumental, though perhaps not definitive. Göçek makes only a passing reference (p. 248) to the first official publications denying any attempt to exterminate the Armenians, two volumes, titled The Armenian Aspirations and Revolutionary Movements, and published by the Ottoman Ministry of the Interior at the start of $1916 .{ }^{3}$ A close analysis of this publication (the language and images) is pivotal to understanding that denial is part of the processes of genocide-denial does not merely manifest itself afterwards, although it can take on different legitimising discourses, as these change (as with this case) over time. ${ }^{4}$

Returning to Göçek's argument-which is that because the Armenian Genocide was an act of foundational violence-helps to explain its continued denial, as well as the endemic

\footnotetext{
${ }^{2}$ Nicholas Doumanis, Before the Nation: Muslim-Christian Coexistence and its Destruction in Late Ottoman Anatolia, (Oxford: Oxford University Press, 2013).

${ }^{3}$ National Archives of the UK, Foreign Office (FO): FO96/212, Toynbee Papers, The Armenian Aspirations and Revolutionary Movements, 2 Volumes, Ottoman Ministry of the Interior, 1916.

${ }^{4}$ I am currently working on an article on this subject.
} 
collective violence against non-Turks throughout the republican era across various generations and governments. This claim is correct in some ways, but incomplete in others. I agree that the Armenian Genocide was an act of foundational violence, but not by those who perpetrated it in 1915 and 1916. Because, at the time, they were aiming at preserving the Ottoman Empire or at least some form of an Ottoman Empire with a dramatically reduced Christian presence. It was those who inherited the genocide, many being Committee of Union and Progress (CUP) officials and members, who included the Armenian Genocide on the script of foundational violence of the new Turkish state, even though it was for other reasons that it was perpetrated. So the reasons to justify the act differed even if the arguments used to do so were similar.

Göçek's Denial of Violence is a must read for anyone interested in the Turkish denial, of its periodic collective violence against Armenians, and to understand Turkish-Armenian relations in the past and present. It is also a must read for those interested in the denial of mass violence against any group of people. Its sociological-historical approach is innovative and should inspire others to adopt it, although they should be mindful to mine the archives for the words (and images) of the perpetrators as well as their published memoirs. 